\title{
Is Gastroesophageal Reflux Disease and Achalasia Coincident or Not?
}

\author{
Da Hyun Jung and Hyojin Park* \\ Department of Internal Medicine, Gangnam Severance Hospital, Yonsei University College of Medicine, Seoul, Korea
}

Achalasia and gastroesophageal reflux disease (GERD) are on opposite ends of the spectrum of lower esophageal sphincter dysfunction. Heartburn is the main symptom of GERD. However, heartburn and regurgitation are frequently observed in patients who have achalasia. The diagnosis of achalasia might be delayed because these symptoms are misinterpreted as gastroesophageal reflux. Here, we reviewed the clinical characteristics of patients with the erroneous diagnosis of GERD who actually had untreated achalasia.

(J Neurogastroenterol Motil 2017;23:5-8)

\section{Key Words}

Esophageal achalasia; Gastroesophageal reflux; Heartburn

\section{Introduction}

Achalasia is a motility disorder characterized by esophageal aperistalsis and nonrelaxation of the lower esophageal sphincter (LES). ${ }^{1}$ Gastroesophageal reflux disease (GERD) is a condition that develops when reflux of gastric contents causes symptoms and complications. ${ }^{2}$ Generally, achalasia and GERD are thought to be at opposite ends of the spectrum of LES dysfunction. In achalasia, the LES may be hypertensive and show impaired relaxation in response to swallowing. ${ }^{3}$ In GERD, the LES can either be hypotensive or display frequent relaxations. Therefore, LES dysfunction in achalasia may serve as a substantial barrier to the reflux of gastric contents, and GERD may not be expected to appear frequently in patients with achalasia. However, there is a portion of overlap between achalasia and GERD, and it is still controversial whether these conditions co-exist or whether one disease transforms into the other.

\section{Overlap Between Gastroesophageal Reflux Disease and Achalasia}

In the early stages of achalasia, chest pain or heartburn, and regurgitation commonly occurs. ${ }^{4-6}$ The sensitivity and the specificity of symptoms are poor indicators of the status of esophageal motility disorder. ${ }^{7}$ Heartburn and regurgitation is the main symptom of GERD, caused by reflux of gastric acid. However, heartburn and regurgitation is frequently observed in patients who have achalasia (Table). Heartburn was reported in $13.2-68.0 \%$ of patients with achalasia. According to a previous report, proton pump inhibitors were prescribed to $53 \%$ of achalasia patients, histamine $\mathrm{H}_{2}$ blockers to $10 \%$, and both to $6 \%$ on the assumption that GERD was the cause of heartburn and regurgitation. ${ }^{8}$ Dysphagia occurs in patients with achalasia and is not easily recognized by patients and physicians. ${ }^{9}$ Spechler et al ${ }^{10}$ demonstrated that in some patients, the

Received: July 23, 2016 Revised: September 12, 2016 Accepted: September 20, 2016

(c) This is an Open Access article distributed under the terms of the Creative Commons Attribution Non-Commercial License (http://creativecommons. org/licenses/by-nc/4.0) which permits unrestricted non-commercial use, distribution, and reproduction in any medium, provided the original work is properly cited.

*Correspondence: Hyojin Park, MD, PhD

Gangnam Severance Hospital, Yonsei University College of Medicine, 211 Eonju-ro, Gangnam-gu, Seoul 06273, Korea Tel: +82-2-2019-3318, Fax: +82-2-3463-3882, E-mail: hjpark21@yuhs.ac 
Table. Symptoms of Achalasia

\begin{tabular}{|c|c|c|c|c|c|c|c|}
\hline $\begin{array}{l}\text { Study } \\
\text { ID }\end{array}$ & Authors & Year & $\begin{array}{l}\text { Heartburn } \\
\text { (n }[\%])\end{array}$ & $\begin{array}{l}\text { Regurgitation } \\
\quad(\mathrm{n}[\%])\end{array}$ & $\begin{array}{l}\text { Chest pain } \\
(\mathrm{n}[\%])\end{array}$ & Participant & Other symptoms (n [\%]) \\
\hline 1 & Patti et $\mathrm{al}^{7}$ & 1997 & $27(67.5)$ & NA & NA & 40 & Dysphagia (40 [100.0]) \\
\hline 2 & Fisichella et al ${ }^{8}$ & 2008 & $75(51.7)$ & $110(75.9)$ & $60(41.4)$ & 145 & $\begin{array}{l}\text { Dysphagia (136 [93.8]), weight loss (51 [35.2]), } \\
\text { aspiration }(18[12.4])\end{array}$ \\
\hline 3 & $\begin{array}{l}\text { Rosenzweig } \\
\text { and Traube }\end{array}$ & 1989 & $10(40.0)$ & $16(64.0)$ & $5(20.0)$ & 25 & $\begin{array}{l}\text { Dysphagia (23 [92.0]), nocturnal cough (9 [36.0]), } \\
\text { weight loss }(12[48.0])\end{array}$ \\
\hline 4 & Spechler et al ${ }^{10}$ & 1995 & $32(47.8)$ & $47(70.1)$ & $35(52.2)$ & 67 & Dysphagia (67 [100.0]), weight loss (37 [55.2]) \\
\hline 5 & Ponce et $\mathrm{al}^{26}$ & 2011 & $15(37.5)$ & NA & NA & 40 & NA \\
\hline 6 & Howard et $\mathrm{al}^{36}$ & 1992 & $5(13.2)$ & NA & NA & 38 & Dysphagia (38 [100.0]), weight loss (23 [60.5]) \\
\hline
\end{tabular}

NA, not applicable.

dissolution of heartburn and regurgitation and appearance of dysphagia could be a symptom of achalasia. In particular, they insisted that achalasia could develop in patients with chronic GERD.

\section{Does Gastroesophageal Reflux Disease Really Progress to Achalasia?}

Several authors have suggested that a spectrum of related esophageal motor disorders exists and that some patients may progress from one type of motor disorder to another. ${ }^{11-15}$ There is no sufficient data to prove whether GERD progresses to achalasia. There are several case reports describing the progression of GERD to achalasia. Smart et $\mathrm{al}^{16}$ described 5 patients with longstanding GERD that antedated the onset of achalasia. Additionally, Robson et $\mathrm{al}^{17}$ showed that GERD progressed to diffuse esophageal spasm and then to achalasia.

\section{Are Gastroesophageal Reflux Disease and Achalasia Coincident Diseases?}

There are several reports that GERD and achalasia are the outcomes of 2 independent disease processes. Heartburn is the form of GERD that results from dysmotility of achalasia. The LES dysfunction in achalasia might be a substantial barrier to reflux. However, some patients occasionally experience episodes of complete LES relaxation, during which gastric contents can enter the esophagus. ${ }^{18}$ The refluxed gastric contents may be poorly cleared from such a dysfunctional esophagus, causing substantial heartburn. This mechanism is supported by previous reports that esophageal acid exposure was documented by $\mathrm{pH}$ monitoring in some patients with achalasia. ${ }^{19,20}$ However, whether the low esophageal $\mathrm{pH}$ in these patients is caused by retention of lactic acid from bacterial fermentation of retained food or true refluxed gastric acid is controversial. Spechler et $\mathrm{al}^{10}$ showed that patients who have achalasia with heartburn have lower basal LES pressure than patients without heartburn. Because GERD and achalasia are 2 coincidental diseases, patients with heartburn have lower basal LES pressure due to GERD. Therefore, patients with heartburn cannot have higher LES pressure when achalasia develops.

\section{Does Reflux Occur in Achalasia?}

Several studies utilizing 24-hour $\mathrm{pH}$ monitoring show that untreated achalasia patients experience true acid reflux..$^{10,17,21,22}$ Conversely, patients with achalasia are insensitive to acid in the esophagus. $^{23}$ Fisichella et $\mathrm{al}^{8}$ reported data from 145 untreated achalasia patients. Among them, ambulatory $\mathrm{pH}$ monitoring was performed for 54 patients. Abnormal DeMeester scores were reported for seven patients. However, the analysis of $\mathrm{pH}$ monitoring tracings in all seven patients showed that the abnormal scores were induced by false reflux. ${ }^{8}$ Otherwise, among those with a normal reflux profile, a primary esophageal motility disorder such as achalasia or diffuse esophageal spasm occurred in $18 \%$ of patients. ${ }^{24}$ Patti et al ${ }^{7}$ demonstrated that DeMeester scores were abnormal in 14 out of 40 achalasia patients for whom preoperative ambulatory $\mathrm{pH}$ was performed. However, true gastroesophageal reflux occurred in 8 patients, and pseudo-gastroesophageal reflux occurred in $6{ }^{7}$

\section{Pathophysiology/Pathogenesis of Heartburn in Achalasia}

In GERD, heartburn results when the esophagus is exposed to gastric contents that reflux across an weak or inappropriate LES relaxation. ${ }^{25}$ In achalasia, heartburn might result from other 
mechanisms. Ponce et $\mathrm{al}^{26}$ demonstrated that patients with achalasia have lower esophageal sensitivity to acid than patients with GERD. Therefore, heartburn does not arise from acid in achalasia. Other possible reasons are as follows. First, retrosternal burning might be due to the esophageal dysmotility of achalasia. Esophageal spasm and distention caused by achalasia might produce sensations like heartburn. ${ }^{10}$ Secondly, ingested irritants that remain in the aperistaltic esophagus might cause heartburn. ${ }^{19}$ In addition, retained food in the flaccid esophagus can be fermented by bacteria into lactic acid. ${ }^{19}$ Crookes et $\mathrm{al}^{27}$ reported that food and saliva at body temperature were fermented to lactic acid by lactobacilli.

\section{Attributing Factors for Diagnostic Delay in Achalasia}

Most patients with achalasia suffer from their symptoms for a prolonged period before receiving a correct diagnosis. ${ }^{28}$ The mean delay in diagnosis is 5 years (range, 2-7 years). ${ }^{29-35}$ Howard et $\mathrm{al}^{36}$ reported that $36.8 \%$ of achalasia patients had been treated for GERD. Additionally, Rosenzweig and Traube ${ }^{9}$ showed that the initial diagnosis was achalasia in only 12 of out 25 achalasia patients, whereas the other 13 patients were diagnosed incorrectly. The most common misdiagnosis in this study was GERD. ${ }^{9}$ Eckardt et $\mathrm{al}^{28}$ demonstrated that the diagnostic delay in achalasia is not significantly associated with atypical symptoms or misleading clinical findings. However, the frequent delay in the diagnosis of achalasia is due to misinterpretation by the physician. Therefore, physician education is important for improving the correct diagnosis. ${ }^{9,28,37}$ Rosenzweig and Traube ${ }^{9}$ insists that patients who complain of dysphagia should be thoroughly evaluated by manometry when obstruction is excluded by barium studies and endoscopic examinations.

\section{Endoscopic Findings in Achalasia}

Esophagitis and Barrett's esophagus were also found in some achalasia patients. ${ }^{22,38}$ Howard et $\mathrm{al}^{36}$ reported that of 34 achalasia patients who underwent endoscopy before manometry, 3 patients showed esophagitis, and one showed esophagitis and stricture. Ponce et $\mathrm{al}^{26}$ showed that esophagitis was present in three out of 40 achalasia patients. Chronic retention of food in patients with achalasia leads to "stagnation" or "retention" esophagitis. ${ }^{39-41}$ By endoscopy, "retention esophagitis" may appear as a mucosal whitish discoloration, mucosal thickening, and nodularity. ${ }^{42}$ Therefore, retention of food that leads to esophagitis, called retention esophagitis, may be clues to avoid erroneous diagnosis of GERD in patients with achalasia.

\section{Conclusions}

Symptoms of GERD are often observed in patients with untreated achalasia. For those patients who do not respond to proton pump inhibitor treatment, esophageal manometry should be performed to exclude esophageal motility disorders including achalasia.

Financial support: None.

Conflicts of interest: None.

\section{References}

1. Boeckxstaens GE, Zaninotto G, Richter JE. Achalasia. Lancet 2014;383:8393.

2. Kahrilas PJ. Gastroesophageal reflux disease. New England Journal of Medicine 2008;359:1700-1707.

3. Youn YH, Minami H, Chiu PW, Park H. Peroral Endoscopic Myotomy for Treating Achalasia and Esophageal Motility Disorders. J Neurogastroenterol Motil 2016;22:14-24.

4. Olsen AM, Holman CB, Andersen HA. The diagnosis of cardiospasm. Dis Chest 1953;23:477-498.

5. Adams CW, Brain RH, Ellis FG, Kauntze R, Trounce JR. Achalasia of the cardia. Guys Hosp Rep 1961;110:191-236.

6. Goldenberg SP, Burrell M, Fette GG, Vos C, Traube M. Classic and vigorous achalasia: a comparison of manometric, radiographic, and clinical findings. Gastroenterology 1991;101:743-748.

7. Patti MG, Arcerito M, Tong J, et al. Importance of preoperative and postoperative $\mathrm{pH}$ monitoring in patients with esophageal achalasia. J Gastrointest Surg 1997;1:505-510

8. Fisichella PM, Raz D, Palazzo F, Niponmick I, Patti MG. Clinical, radiological, and manometric profile in 145 patients with untreated achalasia. World J Surg 2008;32:1974-1979.

9. Rosenzweig $\mathrm{S}$, Traube M. The diagnosis and misdiagnosis of achalasia. A study of 25 consecutive patients. J Clin Gastroenterol 1989;11:147153.

10. Spechler SJ, Souza RF, Rosenberg SJ, Ruben RA, Goyal RK. Heartburn in patients with achalasia. Gut 1995;37:305-308.

11. Narducci F, Bassotti G, Gaburri M, Morelli A. Transition from nutcracker esophagus to diffuse esophageal spasm. Am J Gastroenterol 1985;80:242-244

12. Traube M, Aaronson RM, McCallum RW. Transition from peristaltic esophageal contractions to diffuse esophageal spasm. Arch Intern Med 1986;146:1844-1846

13. Kramer P, Harris LD, Donaldson RM, Jr. Transition from symptomatic diffuse spasm to cardiospasm. Gut 1967;8:115-119.

14. Vantrappen G, Janssens J, Hellemans J, Coremans G. Achalasia, diffuse esophageal spasm, and related motility disorders. Gastroenterology 
1979;76:450-457.

15. Anggiansah A, Bright NF, McCullagh M, Owen WJ. Transition from nutcracker esophagus to achalasia. Dig Dis Sci 1990;35:1162-1166.

16. Smart HL, Mayberry JF, Atkinson M. Achalasia following gastrooesophageal reflux. J R Soc Med 1986;79:71-73.

17. Robson K, Rosenberg S, Lembo T. GERD progressing to diffuse esophageal spasm and then to achalasia. Digestive Diseases and Sciences 2000;45:110-113.

18. Katz PO, Richter JE, Cowan R, Castell DO. Apparent complete lower esophageal sphincter relaxation in achalasia. Gastroenterology 1986;90:978-983.

19. Smart HL, Foster PN, Evans DF, Slevin B, Atkinson M. Twenty four hour oesophageal acidity in achalasia before and after pneumatic dilatation. Gut 1987;28:883-887.

20. Shoenut JP, Trenholm BG, Micflikier AB, Teskey JM. Reflux Patterns in Patients with Achalasia without Operation. Annals of Thoracic Surgery 1988;45:303-305.

21. Shoenut JP, Duerksen D, Yaffe CS. A prospective assessment of gastroesophageal reflux before and after treatment of achalasia patients: pneumatic dilation versus transthoracic limited myotomy. Am J Gastroenterol 1997;92:1109-1112.

22. Sprung DJ, Gibb SP. Barrett's esophagus in a patient with achalasia. Am J Gastroenterol 1985;80:330-333.

23. Shoenut JP, Micflikier AB, Yaffe CS, Denboer B, Teskey JM. Reflux in Untreated Achalasia Patients. Journal of Clinical Gastroenterology 1995;20:6-11.

24. Patti MG, Diener U, Tamburini A, Molena D, Way LW. Role of esophageal function tests in diagnosis of gastroesophageal reflux disease. Dig Dis Sci 2001;46:597-602.

25. Dodds WJ, Hogan WJ, Helm JF, Dent J. Pathogenesis of reflux esophagitis. Gastroenterology 1981;81:376-394.

26. Ponce J, Ortiz V, Maroto N, Ponce M, Bustamante M, Garrigues V. High prevalence of heartburn and low acid sensitivity in patients with idiopathic achalasia. Dig Dis Sci 2011;56:773-776.

27. Crookes PF, Corkill S, DeMeester TR. Gastroesophageal reflux in achalasia. When is reflux really reflux? Dig Dis Sci 1997;42:1354-1361.

28. Eckardt VF, Kohne U, Junginger T, Westermeier T. Risk factors for di- agnostic delay in achalasia. Dig Dis Sci 1997;42:580-585.

29. Sawyers JL, Foster JH. Surgical considerations in the management of achalasia of the esophagus. Ann Surg 1967;165:780-785.

30. Grimes OF, Stephens HB, Margulis AR. Achalasia of the esophagus. Am J Surg 1970;120:198-202.

31. Vantrappen G, Hellemans J, Deloof W, Valembois P, Vandenbroucke J. Treatment of achalasia with pneumatic dilatations. Gut 1971;12:268-275.

32. Black J, Vorbach AN, Collis JL. Results of Heller's operation for achalasia of the oesophagus. The importance of hiatal repair. Br J Surg 1976;63:949-953.

33. Menzies-Gow N, Gummer JW, Edwards DA. Results of Heller's operation for achalasia of the cardia. Br J Surg 1978;65:483-485.

34. Arber N, Grossman A, Lurie B, et al. Epidemiology of achalasia in central Israel. Rarity of esophageal cancer. Dig Dis Sci 1993;38:1920-1925.

35. Fellows IW, Ogilvie AL, Atkinson M. Pneumatic dilatation in achalasia. Gut 1983;24:1020-1023.

36. Howard PJ, Maher L, Pryde A, Cameron EW, Heading RC. Five year prospective study of the incidence, clinical features, and diagnosis of achalasia in Edinburgh. Gut 1992;33:1011-1015.

37. Kawamura O, Hosaka H, Shimoyama Y, et al. Evaluation of proton pump inhibitor-resistant nonerosive reflux disease by esophageal manometry and 24-hour esophageal impedance and $\mathrm{pH}$ monitoring. Digestion 2015;91:19-25.

38. Jaakkola A, Reinikainen P, Ovaska J, Isolauri J. Barrett's esophagus after cardiomyotomy for esophageal achalasia. Am J Gastroenterol 1994;89:165-169.

39. Belsey R. Functional disease of the esophagus. J Thorac Cardiovasc Surg 1966;52:164-188.

40. Király A, Illés A, Undi S, Varga G, Kalmár K, Horváth PO. Gastroesophageal reflux disease progressing to achalasia. Dis Esophagus 2005;18:355-358.

41. Blam ME, Delfyett W, Levine MS, Metz DC, Katzka DA. Achalasia: a disease of varied and subtle symptoms that do not correlate with radiographic findings. Am J Gastroenterol 2002;97:1916-1923.

42. Sleisenger MH, Feldman M, Friedman LS, Brandt LJ. Sleisenger \& Fordtran's gastrointestinal and liver disease : pathophysiology, diagnosis, management. 8th ed. Philadelphia: Saunders, 2006. 